\title{
IMPACT OF AIRFIELD CONCRETE PAVEMENTS DETERIORATION LEVEL ON THE SAFETY OF AIR OPERATIONS
}

\section{WPLYW STOPNIA DEGRADACJI BETONOWYCH NAWIERZCHNI LOTNISKOWYCH NA BEZPIECZEŃSTWO WYKONYWANIA OPERACJI LOTNICZYCH}

\author{
Mariusz Wesołowski, Piotr Barszcz, Krzysztof Blacha
}

Air Force Institute of Technology. Instytut Techniczny Wojsk Lotniczych

\begin{abstract}
The essential factor, which affects the safety of air operations, is the proper airport management based on systemically acquired information regarding the condition of the pavement surfaces of their functional elements. One of the elements in evaluating an airfield pavement technical condition is the assessment of their deterioration degree. This paper contains an extract from a broad study aimed at developing an index characterizing the deterioration degree of cement concrete airfield pavements, based on the results of visual inspections of damage and repairs, and their stock-taking based on a catalogue of common damage and the defined damage and repair quantity surveying principles.
\end{abstract}

Keywords: airfield pavement, deterioration, safety, air operations

Streszczenie: Istotnym czynnikiem, który ma wpływ na bezpieczeństwo wykonywanych operacji lotniczych jest wlaściwe zarzadzanie lotniskami w oparciu o uzyskane $w$ sposób systemowy informacje o stanie nawierzchni ich elementów funkcjonalnych. Jednym z elementów szacowania stanu technicznego nawierzchni lotniskowych jest ocena stopnia ich degradacji. Artykut zawiera wybrany fragment szeroko zakrojonej pracy mającej na celu opracowanie wskaźnika charakteryzującego stopień degradacji nawierzchni lotniskowych wykonanych z betonu cementowego na podstawie wyników przegląów wizualnych uszkodzeń i napraw oraz ich inwentaryzacje $w$ oparciu o katalog typowych uszkodzeń oraz określone zasady obmiarowania uszkodzeń i napraw.

Stowa kluczowe: nawierzchnia lotniskowa, bezpieczeństwo, degradacja, operacje lotnicze 
Impact of airfield concrete pavements deterioration level on the safety of air... Wptyw stopnia degradacji betonowych nawierzchni lotniskowych na...

\section{IMPACT OF AIRFIELD CONCRETE PAVEMENTS DETERIORATION LEVEL ON THE SAFETY OF AIR OPERATIONS}

\section{Introduction}

The safety of air operations is executed by all elements participating in this process, which may be divided into three groups, i.e.: human (onboard personnel, aircraft maintenance personnel, air traffic personnel, airfield equipment operating personnel), aircraft (airplanes, helicopters and other flying objects) and surroundings (airfield, including airfield pavements and air space) [5]. An airfield pavement, in the aspect of air operation execution safety, is characterized by determining its technical condition.

One of the elements of estimating a technical condition of airfield pavements is the evaluation of its degradation (deterioration) degree, which is shown in fig. 1.

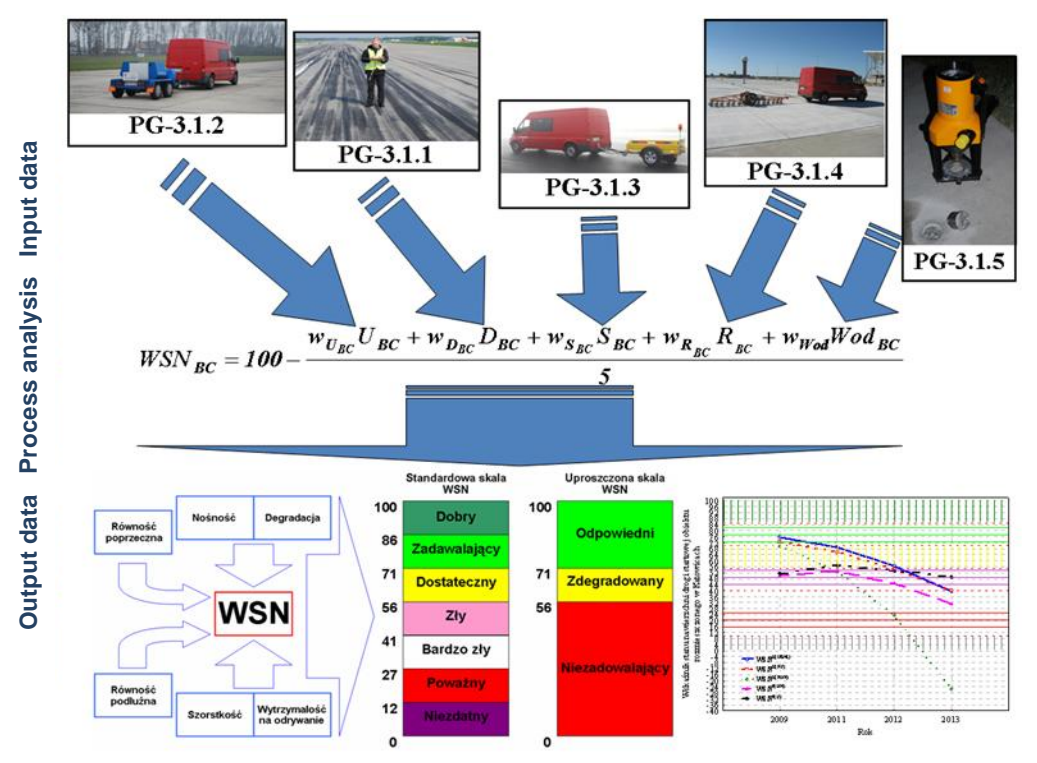

Fig. 1 The process of evaluating an airfield pavement technical condition

Monitoring the technical condition of airfield pavements is extremely important in the aspect of ensuring the safety of air operation. Contemporary military and civilian aircraft require well designed, correctly built and operated airfield pavements. A characteristic feature adopted by the authors of the approach, in order to develop an index characterizing the deterioration degree of cement concrete airfield pavements is that identified damage and conducted repairs for a given date, are taken into account for the evaluation. 
Such an approach allows the planning of resources necessary for such repairs, and rational renovations. Fig. 2 graphically shows the operational strategies for the pavements of airfield functional elements (AFE) - the one used currently is the mixed one [1].

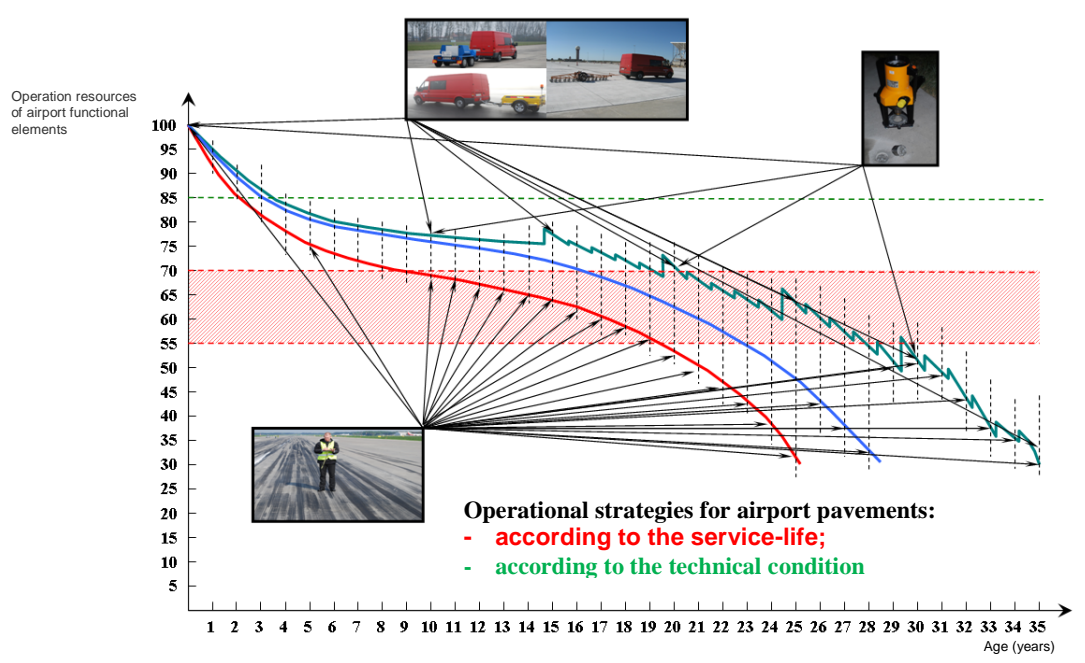

Fig. 2 Operational strategies for pavements of airfield functional elements

The suggested deterioration degree evaluation index, calculated based on the quantity survey of a damage and repair, enables comprehensive assessment of the technical condition of a studied pavement. The basic information necessary for the evaluation of a pavement deterioration degree is obtaining the data regarding stock taking. The paper presents an original method for evaluating airfield pavement (cement concrete) deterioration degree, based on the evaluation criteria for individual parameters characterizing pavement damage and repairs (24 parameters), taking into account the weights characterizing the impact of damage and repairs and individual parameters on the airfield pavement deterioration degree, as well as the impact of replacing slabs, or lack of it, on the deterioration. The method, which was the base for selecting airfield pavement evaluation index weights is an experts' method. The experts' method was based on 5 specialists, dealing with airfield pavement studies. The factors are listed and arranged according to the ranks. The experts assigned each factor with an appropriate weight, taking into account the impact on an airfield pavement technical condition after an inspection and given the aircraft operational safety. The results were developed through the dispersion and variance coefficient analysis, which reflect the experts' views cohesion indices, relative to a given factor. An average weight of an experts' assessment and a variance coefficient are the criteria for proper weight selection. 
Impact of airfield concrete pavements deterioration level on the safety of air... Wptyw stopnia degradacji betonowych nawierzchni lotniskowych na...

\section{Stock taking of damage and repairs}

Due to the destructive processes in cement concrete, and resulting damage, it is essential to conduct periodic inspections of the airfield pavement technical condition, so-called stock taking damage and conducted repairs. Any damage poses a threat to the safety of moving aircraft [4]. The stock taking is conducted based on a catalogue of typical damage to airfield pavements and quantity survey execution principles. Stock taking supporting elements are a damage legend and repairs, and the designations of parameters and their unit. Based on the obtained data regarding the damage and conducted repairs, an airfield pavement deterioration degree is analysed, and the evaluation criteria are determined. It should be noted that a visual method testing, despite its apparent simplicity, is hard to conduct. Classifying damage or repairs to a relevant group is often not explicit, which is why a stock taking process should be standardized. Proper airfield management and providing accurate information about their condition are important factors, which influence the safety of air operations.

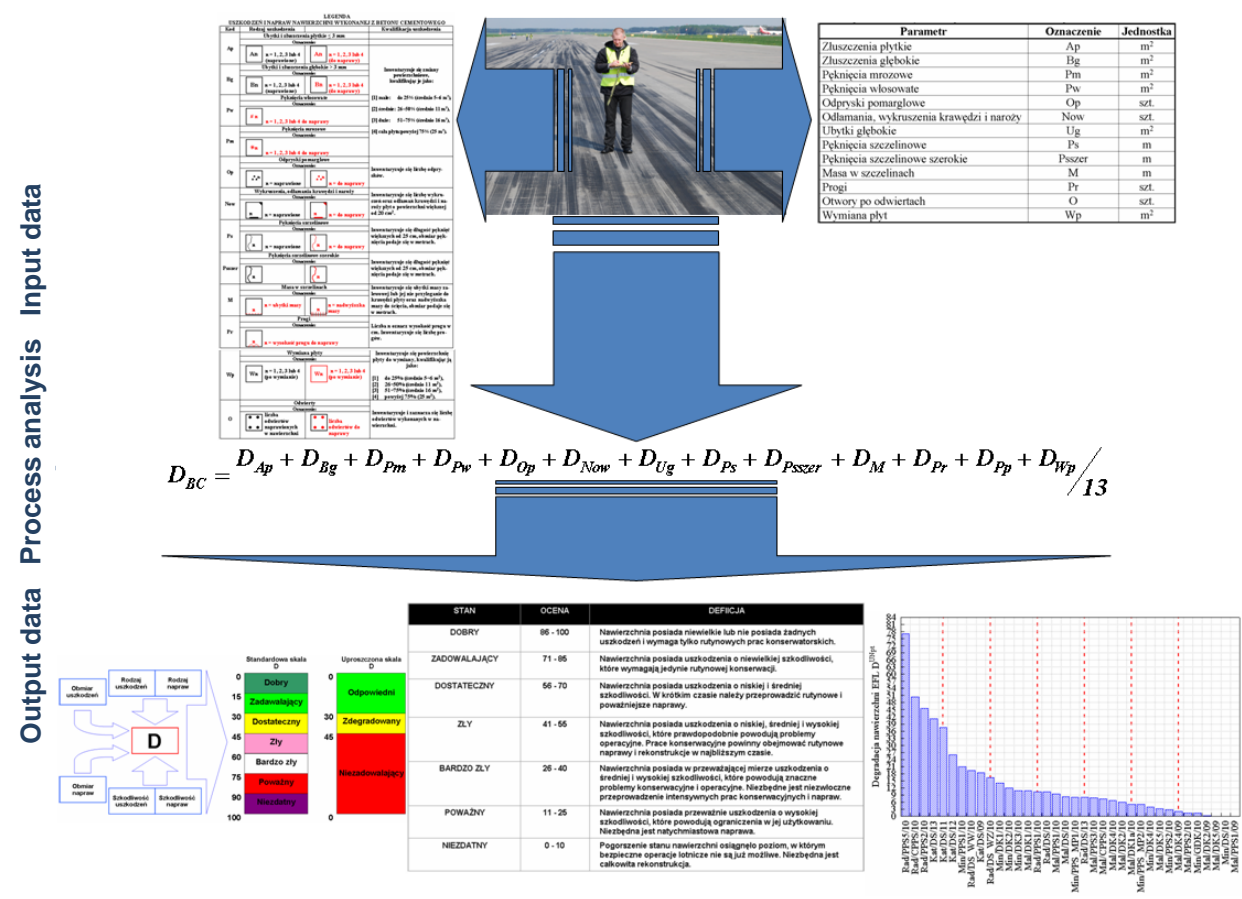

Fig. 3 Airfield pavement deterioration evaluation process

As per the adopted nomenclature, the parameters characterizing airfield pavement deterioration degree are marked, among others, as [2]: shallow and deep flaking; hairline, frost, cavity or wide cavity cracks; marl-related chips; fracturing and chipping of edges and corners; deep defects; sealing material in cavities; boreholes; sills; slabs in need of replacement. 


\section{Estimating the deterioration degree}

Deterioration is a slow process, spread over time. It mainly involves a decline in the structural properties through the impact of external factors, which ultimately generates changes ongoing in the structure. An airfield pavement deterioration level is impacted by damage, as well as the executed repairs. This value was determined on the basis of 13 defined types of damage and repairs. In order to select an optimum index characterizing the actual deterioration degree of an airfield pavement, two calculation variants are considered, which assume that repairs impact pavement deterioration in $20 \%$ or $50 \%$. When analysing the pavement deterioration characterizing indices, the impact of damage and repair types on the safety of aircraft operation is taken into account through introducing appropriately selected weights. A deterioration degree index for airfield functional element pavements, utilizing the occupied surface method, taking into account the impact of a specific parameter on the aircraft operation safety is calculated, based on the data obtained during the stock taking, as per the formulas below [1]:

$$
\begin{aligned}
& \overline{D_{B C}^{M F}}=w_{B C}^{U} \times W_{B C}^{w U F}+w_{B C}^{N} \times W_{B C}^{w N F} \\
& W_{B C}^{w U F}=\sum_{i=1}^{13} \frac{\left(w_{O b}^{U}\right)_{i} \times\left(O b_{B C}^{U}\right)_{i} \times\left(p_{B C}^{U}\right)_{i}}{F} \times 100 \\
& W_{B C}^{w N F}=\sum_{i=1}^{13} \frac{\left(w_{O b}^{N}\right)_{i} \times\left(O b_{B C}^{N}\right)_{i} \times\left(p_{B C}^{N}\right)_{i}}{F} \times 100 / \sum_{i=1}^{13}\left(w_{O b}^{N}\right)_{i}
\end{aligned}
$$

where:

$D_{B C}^{M F}$ - deterioration of an airfield functional element cement concrete pavement,

$p_{i} \quad$ - conversion factor of a damage or repair characterisation parameter to the surface occupying damaged or repaired areas,

$w_{B C}^{i} \quad$ - statistical weight factor of the significance of damage and repairs in the evaluation of AFE pavement deterioration,

$w_{O b i}^{i} \quad$ - statistical weight factor of the significance of specific damage and repairs in the evaluation of AFE pavements,

$O b_{i} \quad$ - quantity survey of AFE pavement damage and repairs,

$F \quad$ - total area of the studied AFE pavement,

$U$ - AFE pavement damage,

$N$ - AFE pavement repairs. 
Impact of airfield concrete pavements deterioration level on the safety of air... Wplyw stopnia degradacji betonowych nawierzchni lotniskowych na...

Deterioration degree index for airfield functional element pavements, utilizing the limit values method, is calculated based on the data obtained in the process of stock taking, as per the formulas below [1]:

$$
\begin{gathered}
\overline{D_{B C}^{M G}}=w_{B C}^{U} \times W_{B C}^{w U G}+w_{B C}^{N} \times W_{B C}^{w N G} \\
W_{B C}^{w U G}=\sum_{i=1}^{13} \frac{\left(w_{O b}^{U}\right)_{i} \times\left(O b_{B C}^{U}\right)_{i}}{F \times\left(W G_{B C}^{U}\right)_{i}} \times 100 \\
W_{B C}^{w N G}=\sum_{i=1}^{13} \frac{\left(w_{O b}^{N}\right)_{i} \times\left(O b_{B C}^{N}\right)_{i}}{F \times\left(W G_{B C}^{N}\right)_{i}} \times 100 \\
\sum_{i=1}^{13}\left(w_{O b}^{U}\right)_{i}
\end{gathered}
$$

where:

$D^{M G}{ }_{B C}$ - deterioration of an airfield functional element cement concrete pavement, $W G_{i} \quad$ - limit value for specific damage and repairs.

A non-burdened deterioration degree index for airfield functional element pavements, utilizing the occupied surface method, is calculated based on the data obtained in the process of stock taking, as per the formulas below [1]:

$$
\overline{D_{B C}^{M F}}=w_{B C}^{U} \times W_{B C}^{U F}+w_{B C}^{N} \times W_{B C}^{N F}
$$

where:

$$
\begin{aligned}
W_{B C}^{U F} & =\sum_{i=1}^{13} \frac{\left(O b_{B C}^{U}\right)_{i} \times\left(p_{B C}^{U}\right)_{i}}{F} \times 100 \\
W_{B C}^{N F} & =\sum_{i=1}^{13} \frac{\left(O b_{B C}^{N}\right)_{i} \times\left(p_{B C}^{N}\right)_{i}}{F} \times 100
\end{aligned}
$$

A non-burdened deterioration degree index for airfield functional element pavements, utilizing the limit values method, is calculated based on the data obtained in the process of stock taking, as per the formulas below [1]:

$$
\overline{D_{B C}^{M G}}=w_{B C}^{U} \times W_{B C}^{U G}+w_{B C}^{N} \times W_{B C}^{N G}
$$

where:

$$
\begin{aligned}
W_{B C}^{U G} & =\sum_{i=1}^{13} \frac{\left(O b_{B C}^{U}\right)_{i}}{F \times\left(W G_{B C}^{U}\right)_{i}} \times 100 \\
W_{B C}^{N G} & =\sum_{i=1}^{13} \frac{\left(O b_{B C}^{N}\right)_{i}}{F \times\left(W G_{B C}^{N}\right)_{i}} \times 100
\end{aligned}
$$


A deterioration degree index for airfield functional element pavements, is calculated as per the formulas below [1]:

$$
\begin{aligned}
& W_{B C}^{U}=w_{B C}^{w U G} \times W_{B C}^{w U G}+w_{B C}^{w U F} \times W_{B C}^{w U F}+w_{B C}^{U G} \times W_{B C}^{U G}+w_{B C}^{U F} \times W_{B C}^{U F} \\
& W_{B C}^{N}=w_{B C}^{w N G} \times W_{B C}^{w N G}+w_{B C}^{w N F} \times W_{B C}^{w N F}+w_{B C}^{N G} \times W_{B C}^{N G}+w_{B C}^{N F} \times W_{B C}^{N F}
\end{aligned}
$$

\section{Assessing the deterioration degree}

The results of visual inspections of airfield pavements were taken into account when estimating the pavement deterioration degrees. The AFE analysis was conducted taking into account whether the slabs had been replaced or not. The analysed spectrum of studied facilities was divided into 7 groups and the boundaries of intervals characterizing the pavement deterioration criteria were determined. The indices that were the basis for estimating the values of pavement deterioration degree evaluation criteria are the non-burdened $D^{U N}$ and weighted $D^{w(U N)}$ indices for the deterioration of airfield functional element pavements, which are determined based on a distinguishing AFE damage $W^{U}$ or repair $W^{N}$. Values achieved by the index characterizing the airfield pavement deterioration, taking into account appropriately selected weights (repairs impact pavement deterioration in 50\%) are shows in fig. 4.

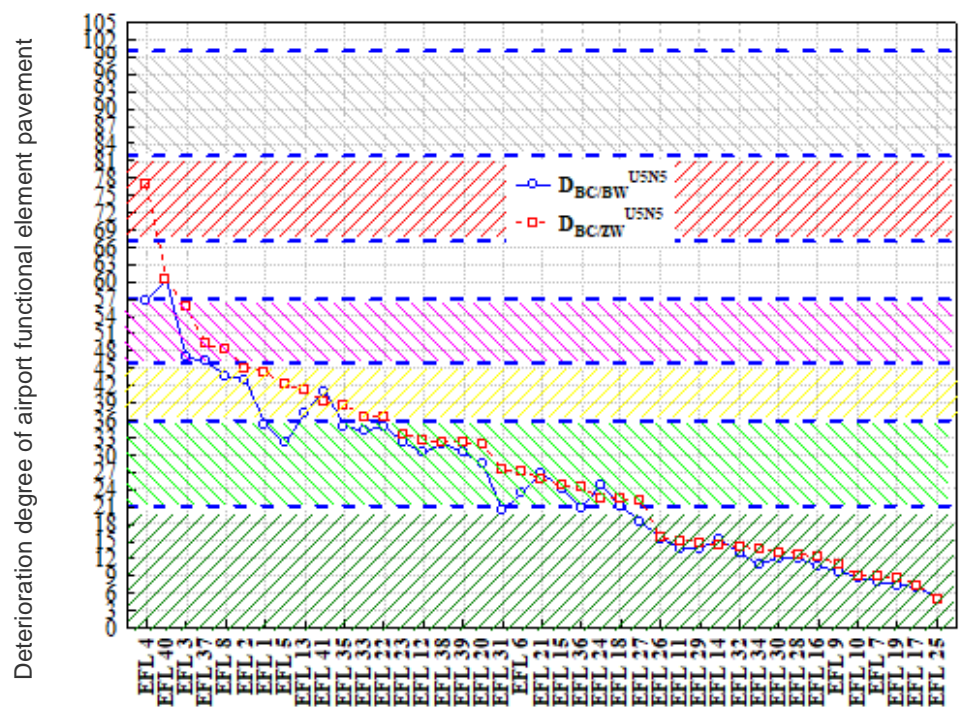

Fig. 4 AFE pavement deterioration degree $D_{B C}{ }^{U S N 5}$

However, it should be noted that in order to obtain a full image of the pavement deterioration condition, the indices characterizing damage and repairs have to be analysed. A histogram in the form of a bar chart was used, in order to graphically depict a determined set of data characterizing the pavement deterioration. 
Impact of airfield concrete pavements deterioration level on the safety of air... Wplyw stopnia degradacji betonowych nawierzchni lotniskowych na...

Organization of a set of raw data involves dividing into ranges, called classes. It enables a presentation of the empirical distribution of the features against quantitative variables and specifies what values most of the results are located at. Based on the analysis of probability distributions, the appropriate distributions corresponding to the nature of the probability density function were selected. Probability refers to the possibility of a certain event or several events. Having the data of the course of a pavement deterioration degree characterizing index, we can determine the probability of a specific event, which adopts a value in the range from 0 to 1 . The probability range for an event is divided into seven intervals, and the possibility of a certain event with a set probability is calculated. The airfield functional element pavement deterioration degree characterizing index falls within the boundaries from 0 , meaning a pavement in ideal condition, to 100, meaning a pavement unfit for further operation. A standard scale for evaluating pavement deterioration degrees includes 7 levels, although a simplified scale can be applied, which distinguishes three levels determining the description of an airfield functional element pavement deterioration degree. Each level has assigned pavement condition determination classes. The first one is a desired level, covering new, renovated and operated pavements, under the assumption that within the next five years these pavements will not require planned renovation work. A warning, intermediate level, identifies a pavement condition as such, in which it is justified to perform thorough tests aimed at treatments improving the condition of the pavement. The last level is the critical level, which stipulates immediate execution of technical-operating tests, in order to determine actions involving treatments improving the pavement condition or decommissioning a facility. Fig. 5 shows the relationship between decision-making levels and the deterioration classes of AFE pavements [1]. A critical value of the $D$ index is such a value, which when reached by a pavement, causes its immediate deterioration.
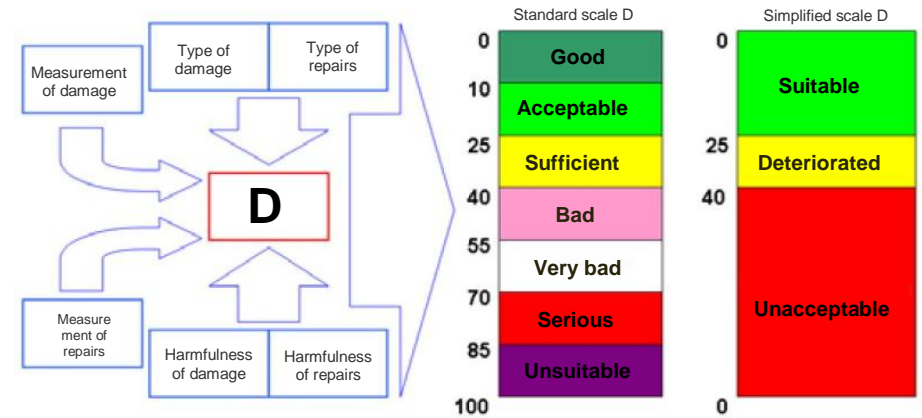

Fig. 5 AFE pavement deterioration degree evaluation criteria proposed by the authors 


\section{Conclusions}

The issue addressed by the authors is extremely important from the point of view of air operation safety. Based on verified parameters, which characterize the deterioration degree of airfield pavements (in the cement concrete technology), it is possible to forecast and estimate a period of safe operation of a specific airfield functional element, which subsequently enables transition to operation of an AFE pavement, according to its technical condition. Airfield pavement (cement concrete) deterioration degree evaluation index, calculated based on the quantity survey of damage and repairs, enables a comprehensive technical condition evaluation of a tested airfield pavement. It should also be noted that for the purpose of a reliable prediction of an airfield pavement condition, it is necessary to apply an objective, repeatable evaluation system.

The presented approach applies to an airfield functional element. Whereas the evaluation of concrete slab deterioration requires another approach. As a result, it is recommended to continue the works in this field aimed at selecting proper parameters and indices characterizing the technical condition and deterioration degree of the slab. Moreover, the authors are working on developing an index characterizing the deterioration degree of airfield pavements executed in the asphalt concrete technology.

\section{Literature}

[1] Barszcz P., Blacha K.: Wielokryterialna metoda oceny stopnia zdegradowania nawierzchni elementów funkcjonalnych lotnisk wykonanych $z$ betonu cementowego [A multi-criteria evaluation method for airfield functional elements cement concrete pavements]. Autobusy-Technika, Eksploatacja, Systemy Transportowe no. 12/2016, p. 48-54.

[2] Barszcz P., Wesołowski M.: Szacowanie kryteriów oceny stopnia zdegradowania funkcjonalnych elementów nawierzchni lotniskowych wykonanych $z$ betonu cementowego na podstawie danych uzyskanych $z$ eksploatowanych obiektów [Estimating the evaluation criteria for the assessment of airfield functional elements cement concrete pavements, based on the data obtained from operated facilities]. Technika Transportu Szynowego nr 12/2015, p. 93-98.

[3] Barszcz P., Wesołowski M.: System oceny stanu technicznego nawierzchni lotniskowych jako element procesu zarzadzania jakościa $w$ lotnictwie wojskowym [Airfield pavement technical condition evaluation system as an element of quality management in military aviation], Logistyka no. 6/2014, p. $1710-1719$.

[4] Blacha K., Wesołowski M.: Nawierzchnie lotniskowe jako element systemu bezpieczeństwa szkolenia lotniczego na obiektach lotniskowych Sit Zbrojnych $R P$. [Airfield pavements as an element of air training safety system at the training facilities of the Polish Armed Forces]. Transport lotniczy i jego otoczenie. Drukarnia Oficyny Wydawniczej Politechniki Warszawskiej. Warszawa 2016. P. 15-25. 
Impact of airfield concrete pavements deterioration level on the safety of air... Wplyw stopnia degradacji betonowych nawierzchni lotniskowych na...

[5] Lewitowicz J.: Eksploatacyjne wtasności $i$ wtaściwości samolotów $i$ śmigłowców [Operational properties and properties of airplanes and helicopters]. Wydawnictwo Instytutu Technicznego Wojsk Lotniczych, Warszawa 2015.

[6] Markowska K.: Proces realizacji usługi transportowej drogowej w centrum dystrybucji wybranego operatora logistycznego. Systemy Logistyczne. Teoria $i$ praktyka, Wydanie I, Oficyna Wydawnicza Politechniki Warszawkiej, Warszawa 2017 r.

[7] Pakiet Statistica PL dla Windows [Windows Statistica PL Package]. Ed. StatSoft, Kraków 2014.

[8] Poświata A., Wesołowski M.: Bezpieczeństwo i niezawodność wykonywania operacji lotniczych na obiektach lotniskowych Sit Zbrojnych RP [Safety and reliability of air operations at airfield facilities of the Polish Armed Forces]. Współczesne problemy logistyki lotnictwa. Teoria i praktyka. Wydawnictwo Wyższej Szkoły Oficerskiej Sił Powietrznych. Dęblin 2015. P. 7-23.

[9] SHAHIN M. Y., Pavement Management For Airports, Road, and Parking Lots. Second edition of 2007.

[10] Smirnow N. N., Ickowicz A. A., Obstuga i remont techniki lotniczej wedtug stanu [Maintenance and repairs of aviation technique according to the condition]. Translation by AFIT. Warszawa 2002.

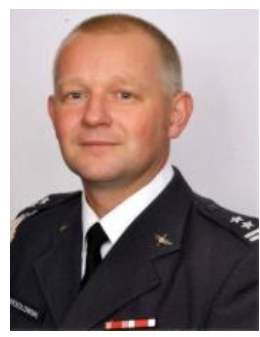

Lt. Col. Mariusz Wesolowski, PhD. Eng., graduated from the Military University of Technology and the Warsaw University of Technology. Head at the Faculty of Airfields at the Air Force Institute of Technology. Specializes in engineering, constructing and evaluating the technical condition of airfield pavement structures (Share 35\%).

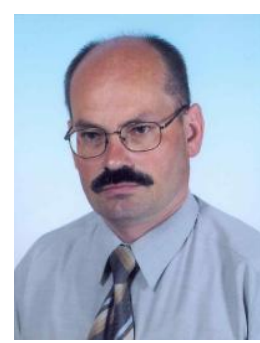

Piotr Barszcz, PhD. Eng., graduated from the Military University of Technology. Assistant Professor at the Faculty of Airfields at the Air Force Institute of Technology. Specializes in the field of corrosion, reliability, safety and operation of aircraft. Participates in works aimed at developing and putting into operation an airfield pavement management system Share $35 \%)$.

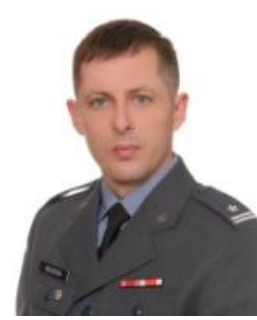

Maj. Krzysztof Blacha, MSc. Eng., graduated from the Department of Military Engineering at the Higher School for Officers of Land Forces and the Department of Civil Engineering and Military Surveying at the Military University of Technology. Laboratory Head at the Faculty of Airfields at the Air Force Institute of Technology. Specializes in engineering, constructing and evaluating the technical condition of airfield pavement structures (Share 30\%). 


\section{WPLYW STOPNIA DEGRADACJI BETONOWYCH NAWIERZCHNI LOTNISKOWYCH NA BEZPIECZEŃSTWO WYKONYWANIA OPERACJI LOTNICZYCH}

\section{Wstęp}

$\mathrm{Na}$ bezpieczeństwo wykonywania operacji lotniczych wpływają wszystkie elementy biorące udział $\mathrm{w}$ tym procesie, które można ując $\mathrm{w}$ trzech grupach, tj.: człowiek (personel pokładowy, personel utrzymujących zdatność statków powietrznych, personel kierujący ruchem lotniczym, personel obsługujący urządzenia lotniskowe), statek powietrzny (samoloty, śmigłowce i inne obiekty latające) oraz otoczenie (lotniska, w tym nawierzchnie lotniskowe oraz przestrzeń powietrzna) [5]. Nawierzchnia lotniskowa w aspekcie bezpieczeństwa wykonywania operacji lotniczych charakteryzowana jest przez określenie jej stanu technicznego.

Jednym z elementów szacowania stanu technicznego nawierzchni lotniskowych jest ocena stopnia ich degradacji (zdegradowania), co przedstawia rys.1.

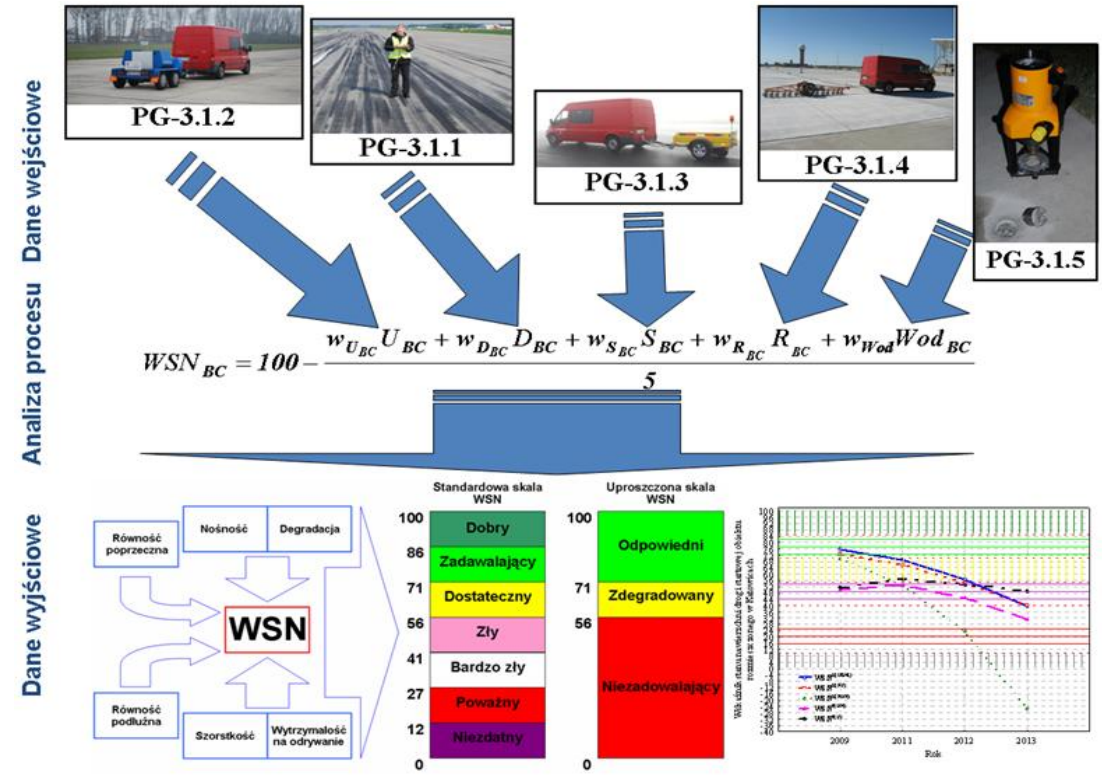

Rys. 1 Proces oceny stanu technicznego nawierzchni lotniskowych

Monitorowanie stanu technicznego nawierzchni lotniskowych jest niezwykle istotne $\mathrm{w}$ aspekcie zapewnienia bezpieczeństwa wykonywania operacji lotniczych. Współczesne, wojskowe i cywilne statki powietrzne wymagają nawierzchni lotniskowych dobrze zaprojektowanych, prawidłowo wybudowanych i eksploatowanych. 
Impact of airfield concrete pavements deterioration level on the safety of air... Wplyw stopnia degradacji betonowych nawierzchni lotniskowych na...

Charakterystyczną cechą przyjętego przez autorów podejścia do opracowania wskaźnika charakteryzującego stopień degradacji nawierzchni lotniskowych wykonanych z betonu cementowego jest to, że do oceny brane są pod uwage stwierdzone uszkodzenia i przeprowadzone naprawy na określony dzień. Takie podejście pozwala na zaplanowanie niezbędnych zasobów potrzebnych do wykonania napraw i racjonalne zaplanowanie remontów. $\mathrm{Na}$ rys. 2 przedstawiono w sposób graficzny strategie eksploatacji nawierzchni elementów funkcjonalnych lotniska (EFL) - obecnie stosowana jest strategia mieszana [1].

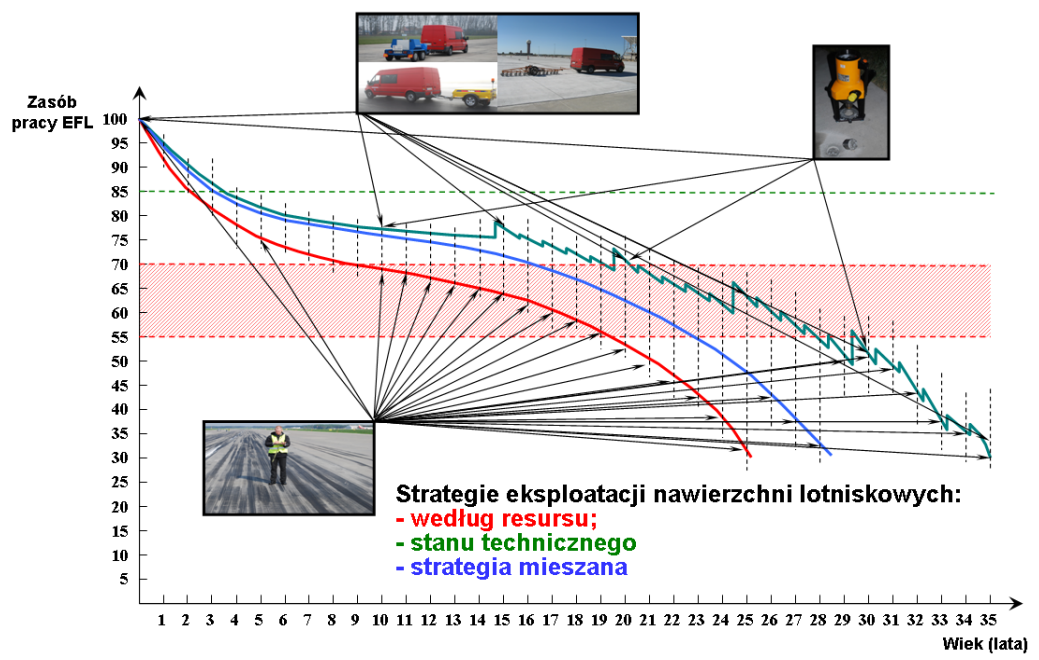

Rys. 2 Strategie eksploatacji nawierzchni elementów funkcjonalnych lotniska

Zaproponowany wskaźnik oceny stopnia degradacji obliczany w oparciu o obmiarowane uszkodzenia i naprawy pozwala na całościową ocenę stanu technicznego powierzchni badanej nawierzchni. Podstawową informacją niezbędną do przeprowadzenia oceny stopnia degradacji nawierzchni jest pozyskanie danych z przeprowadzonej inwentaryzacji. W pracy przedstawiono autorską metodę oceny stopnia degradacji nawierzchni lotniskowych (wykonanych $\mathrm{z}$ betonu cementowego) w oparciu o kryteria oceny poszczególnych parametrów charakteryzujących uszkodzenia i naprawy nawierzchni (24 parametrów), uwzględniając przy tym wagi charakteryzujące wpływ uszkodzeń i napraw oraz poszczególnych parametrów na stopień degradacji nawierzchni lotniskowych, a także wpływ na degradację wymiany płyt lub jej brak. Metoda, w oparciu o którą dobrano wagi wskaźników oceny nawierzchni lotniskowych jest metoda ekspertów. Metodę ekspertów oparto na 5 specjalistach zajmujących się badaniami nawierzchni lotniskowych. Zestawiono i uszeregowano czynniki według rang. Każdemu czynnikowi przypisano przez ekspertów odpowiednią wagę uwzględniając wpływ na stan techniczny nawierzchni lotniskowej po wykonaniu przeglądu i mając na uwadze bezpieczeństwo eksploatacji statków powietrznych. 
Opracowano wyniki poprzez analizę dyspersji i współczynnika wariancji, które przedstawiają sobą wskaźniki zgodności poglądów ekspertów w odniesieniu do danego czynnika. Średnia waga oceny ekspertów i współczynnik wariancji stanowią kryteria właściwego doboru wag.

\section{Inwentaryzacja uszkodzeń i napraw}

Ze względu na procesy destrukcyjne zachodzące $w$ betonie cementowym i pojawiające się $\mathrm{W}$ związku $\mathrm{z}$ tym uszkodzenia, istotne jest wykonywanie okresowych przeglądów stanu technicznego nawierzchni lotniskowych, tzw. inwentaryzacji uszkodzeń oraz wykonanych napraw. Wszelkiego rodzaju uszkodzenia, stwarzają zagrożenie dla bezpieczeństwa poruszających się statków powietrznych [4]. Inwentaryzację prowadzi się w oparciu o katalog typowych uszkodzeń nawierzchni lotniskowych i zasady prowadzenia obmiaru. Elementami wspomagającymi proces inwentaryzacji jest legenda uszkodzeń i napraw oraz oznaczenia parametrów i ich jednostki. W oparciu o uzyskane dane o uszkodzeniach i przeprowadzonych naprawach analizuje się stopień degradacji nawierzchni lotnisk i określa się kryteria oceny. Należy zaznaczyć, że badanie metodą wizualną, mimo swojej pozornej prostoty, jest trudne do wykonania. Kwalifikacja uszkodzeń czy napraw do odpowiedniej grupy często nie jest jednoznaczna, dlatego też proces inwentaryzacji powinien być unormowany. Właściwe zarządzanie lotniskami oraz przekazywanie rzetelnej informacji o ich stanie to istotne czynniki, które mają wpływ na bezpieczeństwo wykonywanych operacji lotniczych.

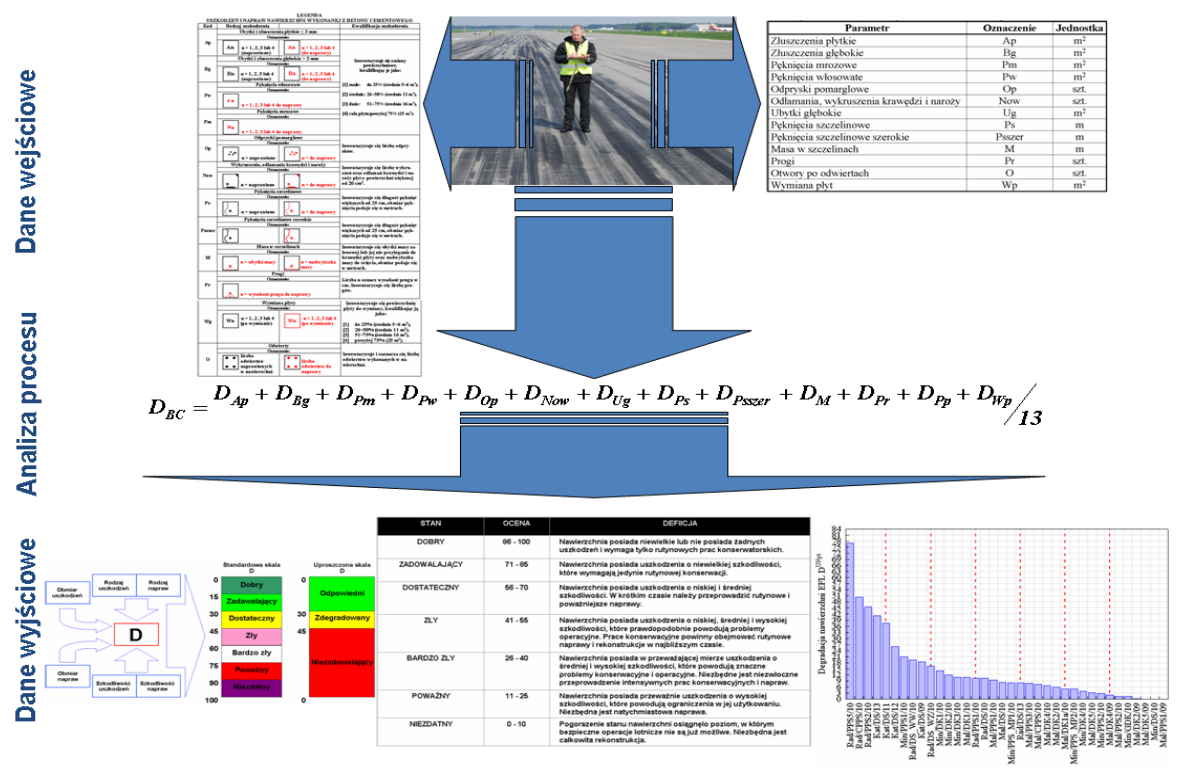

Rys. 3 Proces oceny degradacji nawierzchni lotniskowych 
Impact of airfield concrete pavements deterioration level on the safety of air... Wplyw stopnia degradacji betonowych nawierzchni lotniskowych na...

Zgodnie z przyjętą nomenklaturą, parametry charakteryzujące stopień degradacji nawierzchni lotniskowej oznacza się między innymi jako [2]: złuszczenia płytkie i głębokie; pęknięcia włosowate, mrozowe, szczelinowe, szczelinowe szerokie; odpryski pomarglowe; odłamania, wykruszenia krawędzi i naroży; ubytki głębokie; masa w szczelinach; progi; odwierty; płyty do wymiany.

\section{Szacowanie stopnia degradacji}

Degradacja jest to proces powolny i rozłożony w czasie. Polega on głównie na obniżeniu właściwości konstrukcji poprzez oddziaływanie czynników zewnętrznych, co w efekcie generuje zmiany zachodzące w jej strukturze. $\mathrm{Na}$ poziom zdegradowania nawierzchni elementu funkcjonalnego lotniska wpływają uszkodzenia jak i wykonane naprawy. Tą wielkość określono na podstawie 13 zdefiniowanych rodzajów uszkodzeń i napraw. W celu optymalnego dobrania wskaźnika charakteryzującego rzeczywisty stopień zdegradowania powierzchni nawierzchni, rozpatruje się dwa warianty obliczeń, gdzie zakłada się, że wykonanie napraw wpływa w $20 \%$ lub $50 \%$ na zdegradowanie nawierzchni. Przy analizie wskaźników charakteryzujących zdegradowanie nawierzchni wpływ rodzajów uszkodzeń i napraw na bezpieczeństwo eksploatacji statków powietrznych uwzględnia się poprzez wprowadzenie odpowiednio dobranych wag. Wskaźnik oceny stopnia zdegradowania nawierzchni elementów funkcjonalnych lotnisk przy wykorzystaniu metody zajętej powierzchni przy uwzględnieniu wpływu określonego parametru na bezpieczeństwo eksploatacji statków powietrznych oblicza się na podstawie danych uzyskanych podczas inwentaryzacji zgodnie ze wzorami przedstawionymi poniżej [1]:

$$
\begin{gathered}
\overline{D_{B C}^{M F}{ }_{w}}=w_{B C}^{U} \times W_{B C}^{w U F}+w_{B C}^{N} \times W_{B C}^{w N F} \\
W_{B C}^{w U F}=\sum_{i=1}^{13} \frac{\left(w_{O b}^{U}\right)_{i} \times\left(O b_{B C}^{U}\right)_{i} \times\left(p_{B C}^{U}\right)_{i}}{F} \times 100 \\
W_{B C}^{w N F}=\sum_{i=1}^{13} \frac{\left(w_{O b}^{N}\right)_{i} \times\left(O b_{B C}^{N}\right)_{i} \times\left(p_{B C}^{N}\right)_{i}}{F} \times 100 \\
F
\end{gathered}
$$


gdzie:

$D_{B C}^{M F}$ - zdegradowanie nawierzchni elementu funkcjonalnego lotniska wykonanego $\mathrm{z}$ betonu cementowego,

$p_{i} \quad$ - przelicznik parametru charakteryzującego uszkodzenia lub naprawy na powierzchnię obejmującą uszkodzone lub naprawione obszary,

$w_{B C}^{i}$ - waga statystyczna ważności uszkodzeń i napraw $\mathrm{w}$ ocenie degradacji nawierzchni EFL,

$w_{O b i}^{i}$ - waga statystyczna ważności określonych uszkodzeń i napraw $\mathrm{w}$ ocenie degradacji nawierzchni EFL,

$O b_{i} \quad$ - obmiar uszkodzeń i napraw nawierzchni EFL,

$F \quad$ - powierzchnia całkowita badanej nawierzchni EFL,

$U$ - uszkodzenia nawierzchni EFL,

$N \quad$ - naprawy nawierzchni EFL.

Wskaźnik oceny stopnia zdegradowania nawierzchni elementów funkcjonalnych lotnisk przy wykorzystaniu metody wartości granicznych oblicza się na podstawie danych uzyskanych podczas inwentaryzacji zgodnie ze wzorami przedstawionymi poniżej [1]:

$$
\begin{aligned}
\overline{D_{B C}^{M G}{ }_{w}}= & w_{B C}^{U} \times W_{B C}^{w U G}+w_{B C}^{N} \times W_{B C}^{w N G} \\
W_{B C}^{w U G}= & \sum_{i=1}^{13} \frac{\left(w_{O b}^{U}\right)_{i} \times\left(O b_{B C}^{U}\right)_{i}}{F \times\left(W G_{B C}^{U}\right)_{i}} \times 100 \\
W_{B C}^{w N G}= & \sum_{i=1}^{13} \frac{\left(w_{O b}^{N}\right)_{i} \times\left(O b_{B C}^{N}\right)_{i}}{F \times\left(W G_{B C}^{N}\right)_{i}} \times 100
\end{aligned}
$$

gdzie:

$$
\begin{aligned}
& D_{B C}^{M G} \text { - zdegradowanie nawierzchni elementu funkcjonalnego lotniska } \\
& \quad \text { wykonanego z betonu cementowego, } \\
& W G_{i} \text { - wartość graniczna dla określonych rodzajów i napraw. }
\end{aligned}
$$

Wskaźnik nieobciążony oceny stopnia zdegradowania nawierzchni elementów funkcjonalnych lotnisk przy wykorzystaniu metody zajętej powierzchni oblicza się na podstawie danych uzyskanych podczas inwentaryzacji zgodnie ze wzorem [1]:

$$
\overline{D_{B C}^{M F}}=w_{B C}^{U} \times W_{B C}^{U F}+w_{B C}^{N} \times W_{B C}^{N F}
$$

gdzie:

$$
\begin{aligned}
W_{B C}^{U F} & =\sum_{i=1}^{13} \frac{\left(O b_{B C}^{U}\right)_{i} \times\left(p_{B C}^{U}\right)_{i}}{F} \times 100 \\
W_{B C}^{N F} & =\sum_{i=1}^{13} \frac{\left(O b_{B C}^{N}\right)_{i} \times\left(p_{B C}^{N}\right)_{i}}{F} \times 100
\end{aligned}
$$


Impact of airfield concrete pavements deterioration level on the safety of air... Wptyw stopnia degradacji betonowych nawierzchni lotniskowych na...

Wskaźnik nieobciążony oceny stopnia zdegradowania nawierzchni elementów funkcjonalnych lotnisk przy wykorzystaniu metody wartości granicznych oblicza się na podstawie danych uzyskanych podczas inwentaryzacji zgodnie ze wzorem [1]:

$$
\overline{D_{B C}^{M G}{ }_{w}}=w_{B C}^{U} \times W_{B C}^{U G}+w_{B C}^{N} \times W_{B C}^{N G}
$$

gdzie:

$$
\begin{aligned}
W_{B C}^{U G} & =\sum_{i=1}^{13} \frac{\left(O b_{B C}^{U}\right)_{i}}{F \times\left(W G_{B C}^{U}\right)_{i}} \times 100 \\
W_{B C}^{N G} & =\sum_{i=1}^{13} \frac{\left(O b_{B C}^{N}\right)_{i}}{F \times\left(W G_{B C}^{N}\right)_{i}} \times 100
\end{aligned}
$$

Wskaźnik oceny stopnia zdegradowania nawierzchni elementów funkcjonalnych lotnisk oblicza się zgodnie ze wzorem [1]:

$$
\begin{aligned}
& W_{B C}^{U}=w_{B C}^{w U G} \times W_{B C}^{w U G}+w_{B C}^{w U F} \times W_{B C}^{w U F}+w_{B C}^{U G} \times W_{B C}^{U G}+w_{B C}^{U F} \times W_{B C}^{U F} \\
& W_{B C}^{N}=w_{B C}^{w N G} \times W_{B C}^{w N G}+w_{B C}^{w N F} \times W_{B C}^{w N F}+w_{B C}^{N G} \times W_{B C}^{N G}+w_{B C}^{N F} \times W_{B C}^{N F}
\end{aligned}
$$

\section{Ocena stopnia degradacji}

Przy szacowaniu stopnia zdegradowania nawierzchni brano pod uwage wyniki badań uzyskane podczas wykonywania przeglądów metodą wizualną powierzchni nawierzchni obiektów lotniskowych. Analizę prowadzono dla EFL biorąc przy analizie pod uwagę fakt czy wymieniono lub nie wymieniono płyty. Analizowane spektrum badanych obiektów podzielono na 7 grup i określono granice przedziałów charakteryzujących kryteria oceny zdegradowania nawierzchni. Wskaźnikami, w oparciu, o które szacowano wartości kryteriów oceny stopnia zdegradowania nawierzchni jest wskaźnik nieobciążony $D^{U N}$ oraz ważony w $D^{w(U N)}$ stopnia zdegradowania elementów funkcjonalnych lotniska, które określa się na podstawie wskaźnika charakteryzującego uszkodzenia $W^{U}$ oraz naprawy $W^{N}$ EFL. Wartości, jakie osiągnął wskaźnik charakteryzujący zdegradowanie nawierzchni lotniskowych przy uwzględnieniu odpowiednio dobranych wag (naprawy wpływają w 50\% na zdegradowanie nawierzchni) przedstawiono na rys. 4 .

Jednak należy zaznaczyć, że dla pełnego obrazu stanu zdegradowania nawierzchni należy przeanalizować wskaźniki charakteryzujące uszkodzenia i naprawy. Dla graficznego zobrazowaniem zmienności określonego zbioru danych charakteryzujących zdegradowanie nawierzchni wykorzystano histogram, który ma postać wykresu słupkowego. 
Uporządkowanie zbioru danych surowych polega na podziale na przedziały zwane klasami. Pozwala to na przedstawienie rozkładu empirycznego cech dla zmiennych ilościowych, określa, przy jakich wartościach zlokalizowana jest większość wyników.

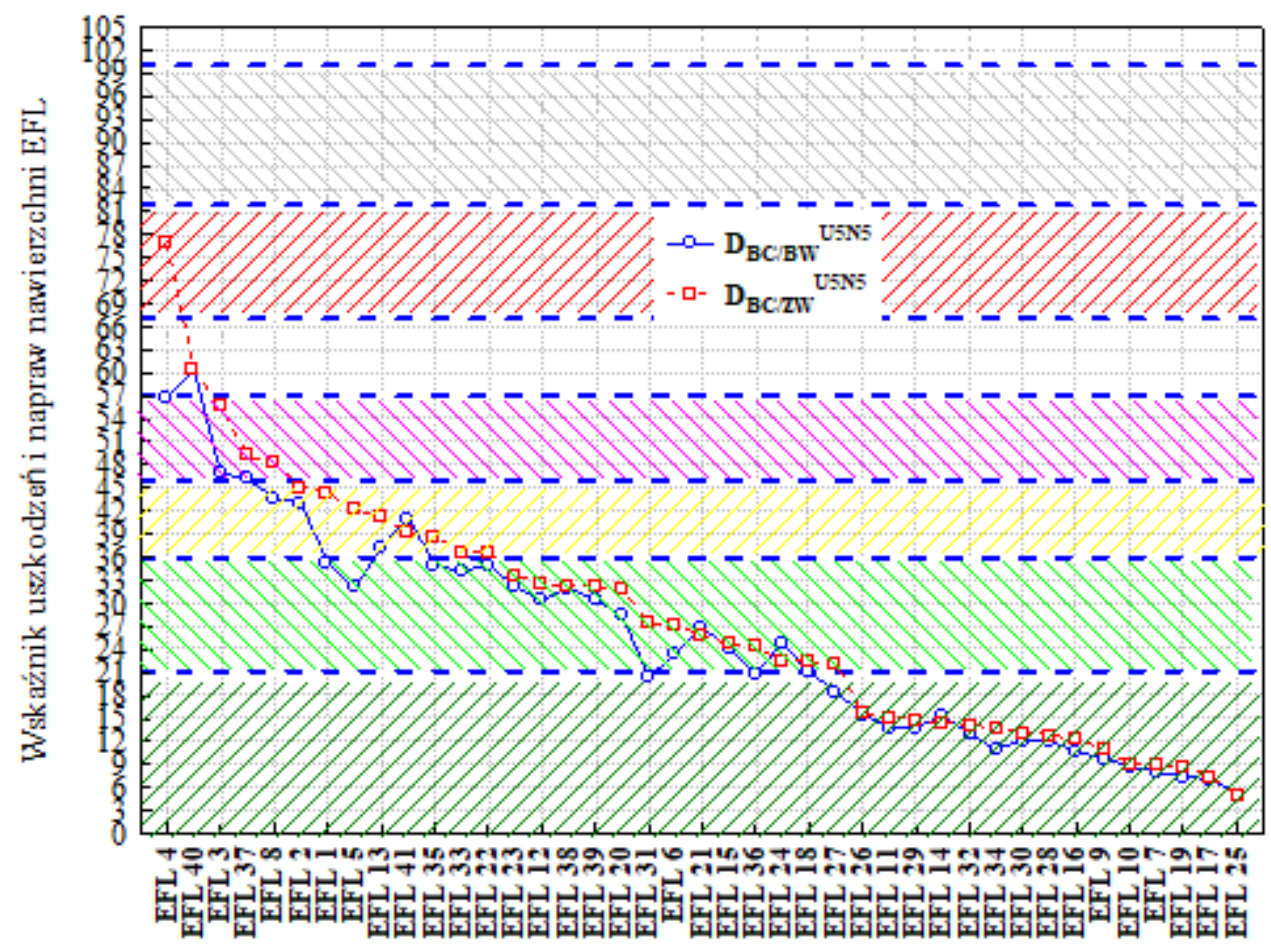

Rys. 4 Stopień zdegradowania $D_{B C}{ }^{U S N 5}$ nawierzchni EFL

W oparciu o analizę rozkładów prawdopodobieństwa dobrano odpowiednie rozkłady odpowiadające charakterowi funkcji gęstości prawdopodobieństwa. Prawdopodobieństwo odnosi się do możliwości wystąpienia jakiegoś zdarzenia bądź kilku zdarzeń. Mając dane przebiegu wskaźnika charakteryzującego stopień zdegradowania nawierzchni wyznaczamy prawdopodobieństwo wystąpienia określonego zdarzenia, który przyjmuje wartości w zakresie od 0 do 1 . Zakres prawdopodobieństwa wystąpienia zdarzenia dzielimy na siedem przedziałów i obliczamy możliwość pojawienia się określonego zdarzenia $\mathrm{z}$ zadanym prawdopodobieństwem. Zaproponowany przez autorów wskaźnik charakteryzujący stopień degradacji nawierzchni elementów funkcjonalnych lotniska mieści się w granicach od wartości 0 oznaczającej nawierzchnię w stanie idealnym do wartości 100 oznaczającej nawierzchnię niezdatną do dalszej eksploatacji. 
Impact of airfield concrete pavements deterioration level on the safety of air... Wptyw stopnia degradacji betonowych nawierzchni lotniskowych na...

Standardowa skala oceny stopnia zdegradowania nawierzchni obejmuje 7 poziomów, chociaż można też stosować uproszczoną skalę, gdzie wyróżnia się trzy poziomy decyzyjne opisu stopnia zdegradowania nawierzchni elementu funkcjonalnego lotniska. Dla każdego poziomu przypisano klasy determinujące stan nawierzchni. Pierwszy to poziom pożądany, który obejmuje nawierzchnie nowe, odnowione i eksploatowane, przy założeniu, iż w przeciągu kolejnych pięciu lat nawierzchnie te nie będą wymagały planowanych prac remontowych.

Poziom ostrzegawczy, pośredni, identyfikuje stan nawierzchni jako taki, w którym uzasadnione jest wykonanie badań szczegółowych w kierunku przeprowadzenia zabiegów poprawiających stan nawierzchni. Ostatni to poziom krytyczny, determinujący natychmiastowe wykonanie badań techniczno-eksploatacyjnych, w celu ustalenia czynności mających za zadanie wprowadzenie zabiegów poprawiających stan nawierzchni lub wyłączenie obiektu z eksploatacji.

Na rys. 5 przedstawiono relacje poziomów decyzyjnych i klas stanu zdegradowania nawierzchni EFL [1]. Wartość krytyczna wskaźnika $D$ jest to taka wartość, po osiągnięciu, której stan nawierzchni zaczyna ulegać gwałtownemu pogorszeniu.
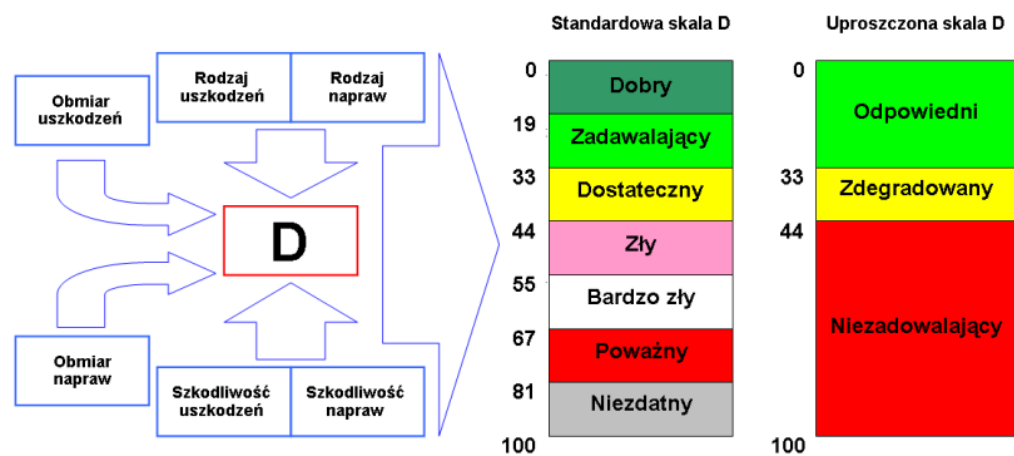

Rys. 5 Kryteria oceny stopnia degradacji nawierzchni EFL zaproponowane przez autorów

\section{Podsumowanie}

Poruszony przez autorów problem jest niezwykle istotny z punktu widzenia bezpieczeństwa wykonywania operacji lotniczych. W oparciu o zweryfikowane parametry charakteryzujące stopień degradacji nawierzchni lotniskowych (wykonanych w technologii betonu cementowego) można prognozować i szacować okres bezpiecznej eksploatacji określonego elementu funkcjonalnego lotniska, co w efekcie umożliwia na przejście do eksploatacji nawierzchni EFL według stanu technicznego. Wskaźnik oceny stopnia degradacji nawierzchni lotniskowych (wykonanych $\mathrm{z}$ betonu cementowego), obliczany w oparciu o obmiarowane uszkodzenia i naprawy pozwala na całościową ocenę stanu technicznego powierzchni badanej nawierzchni. 
Należy również zaznaczyć, że $\mathrm{w}$ celu wiarygodnego przewidywania stanu nawierzchni lotniskowej niezbędne jest zastosowanie obiektywnego, powtarzalnego systemu oceny.

Przedstawione podejście dotyczy elementu funkcjonalnego lotniska. Natomiast ocena zdegradowania pojedynczej płyty betonowej wymaga innego podejścia. $\mathrm{W}$ związku z tym wskazane jest kontynuowanie prac w tym obszarze, celem dobrania właściwych parametrów i wskaźników charakteryzujących stan techniczny oraz stopień zdegradowania płyty. Ponadto, autorzy prowadzą prace mające na celu opracowanie wskaźnika charakteryzującego stopień degradacji nawierzchni lotniskowych wykonanych w technologii betonu asfaltowego.

\section{Literatura}

[1] Barszcz P., Blacha K.: Wielokryterialna metoda oceny stopnia zdegradowania nawierzchni elementów funkcjonalnych lotnisk wykonanych $z$ betonu cementowego. Autobusy-Technika, Eksploatacja, Systemy Transportowe nr 12/2016, str. 48-54.

[2] Barszcz P., Wesołowski M.: Szacowanie kryteriów oceny stopnia zdegradowania funkcjonalnych elementów nawierzchni lotniskowych wykonanych $z$ betonu cementowego na podstawie danych uzyskanych $z$ eksploatowanych obiektów. Technika Transportu Szynowego nr 12/2015, str. 93-98.

[3] Barszcz P., Wesołowski M.: System oceny stanu technicznego nawierzchni lotniskowych jako element procesu zarzadzania jakościa $w$ lotnictwie wojskowym, Logistyka nr 6/2014, str. 1710-1719.

[4] Blacha K., Wesołowski M.: Nawierzchnie lotniskowe jako element systemu bezpieczeństwa szkolenia lotniczego na obiektach lotniskowych Sił Zbrojnych $R P$. Transport lotniczy i jego otoczenie. Drukarnia Oficyny Wydawniczej Politechniki Warszawskiej. Warszawa 2016. Str. 15-25.

[5] Lewitowicz J.: Eksploatacyjne własności $i$ właściwości samolotów $i$ śmigłowców. Wydawnictwo Instytutu Technicznego Wojsk Lotniczych, Warszawa 2015.

[6] Markowska K.: Proces realizacji usługi transportowej drogowej w centrum dystrybucji wybranego operatora logistycznego. Systemy Logistyczne. Teoria $i$ praktyka, Wydanie I, Oficyna Wydawnicza Politechniki Warszawkiej, Warszawa 2017 r.

[7] Pakiet Statistica PL dla Windows. Wyd. StatSoft, Kraków 2014. 
Impact of airfield concrete pavements deterioration level on the safety of air... Wplyw stopnia degradacji betonowych nawierzchni lotniskowych na...

[8] Poświata A., Wesołowski M.: Bezpieczeństwo i niezawodność wykonywania operacji lotniczych na obiektach lotniskowych Sit Zbrojnych RP. Współczesne problemy logistyki lotnictwa. Teoria i praktyka. Wydawnictwo Wyższej Szkoły Oficerskiej Sił Powietrznych. Dęblin 2015. Str. 7-23.

[9] SHAHIN M. Y., Pavement Management For Airports, Road, and Parking Lots. Wydanie drugie z roku 2007.

[10] Smirnow N. N., Ickowicz A. A., Obshuga i remont techniki lotniczej wedtug stanu. Tłumaczenie ITWL. Warszawa 2002.

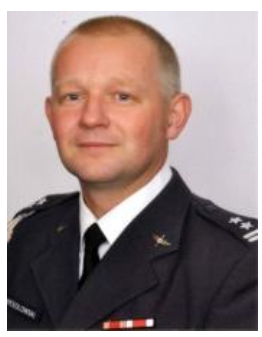

Pptk dr inz. Mariusz Wesolowski, absolwent Wojskowej Akademii Technicznej i Politechniki Warszawskiej. Kierownik Zakładu Lotniskowego w Instytucie Technicznym Wojsk Lotniczych. Specjalizuje sie w projektowaniu, budowie i ocenie stanu technicznego konstrukcji nawierzchni lotniskowych (Udziat 35\%).

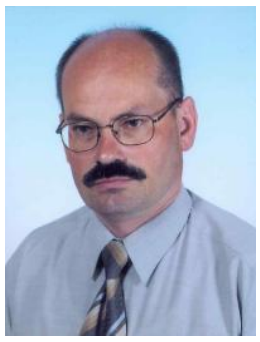

Dr inz. Piotr Barszcz, absolwent Wojskowej Akademii Technicznej. Adiunkt $w$ Zakładzie Lotniskowym $w$ Instytucie Technicznym Wojsk Lotniczych. Specjalizuje się $w$ tematyce korozji, niezawodności, bezpieczeństwa i eksploatacji statków powietrznych. Uczestniczy $w$ pracach majacych na celu opracowanie $i$ wdrożenie do eksploatacji systemu zarzadzania nawierzchniami lotniskowymi (Udział 35\%).

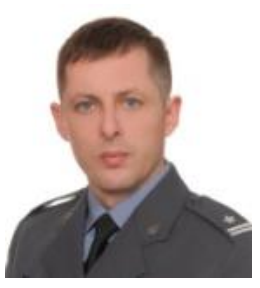

Mjr mgr inz. Krzysztof Blacha, absolwent Wydziatu Inżynierii Wojskowej Wyższej Szkoty Oficerskiej Wojsk Ladowych i Wydziatu Inżynierii Ladowej i Geodezji Wojskowej Akademii Technicznej. Kierownik Pracowni w Zakładzie Lotniskowym w Instytucie Technicznym Wojsk Lotniczych. Specjalizuje sie w projektowaniu, budowie $i$ ocenie stanu technicznego konstrukcji nawierzchni lotniskowych (Udziat 30\%) 